UDK 665.52:635.7]:632.38

632.38:633.71

\title{
ANTIPHYTOVIRAL EFFECTS OF THREE DIFFERENT ESSENTIAL OILS ON TOBACCO MOSAIC VIRUS
}

\section{Antifitoviralno djelovanje tri različita eterična ulja na virus mozaika duhana}

\author{
Anesa Jerković-Mujkić ${ }^{1}$, Irma Mahmutović ${ }^{1}$, Renata Bešta-Gajević ${ }^{1}$
}

\begin{abstract}
Numerous studies have found that essential oils have significant inhibitory activity against human viruses, but there is scarce information on the effects of essential oils on plant viruses. In this study, effects of cajuput (Melaleuca leucadendron (L.) L.), common myrtus (Myrtus communis L.) and winter savory (Satureja montana L.) essential oils were assayed against Tobacco mosaic virus (TMV) by inoculation in different plant host systems. Antiphytoviral activity of the essential oils was determined by the half-leaf method using test plants: Chenopodium quinoa Willd., Cucumis sativus L. 'Cornishon' and Phaseolus vulgaris L. 'Top Crop'. Results showed that investigated oils posess strong antiviral activities. Among tested oils, the highest and broadest acitivity was shown by winter savory essential oil. Evidence suggests that investigated essential oils are possible antiphytoviral agents.
\end{abstract}

Key words: anti phytoviral activity, essential oil, Tobacco mosaic virus

\section{INTRODUCTION - Uvod}

Essential oils are secondary metabolites of plants, stored in the flowers, leaves, fruits, roots, rhizomes, and bark. They are complex mixtures of organic compounds which belong to different chemical classes: aliphatic, aromaticand hydroaromatic substances, hydrocarbons, alcohols, aldehydes, ketones, esters, phenols, acids, etc. (WALLACE, 2004; PICHERSKY ET AL., 2006; REDŽIĆ ET AL., 2006; BASSOLE AND JULIANI, 2012). Several techniques can be used to extract essential oils from different parts of the aromatic plant, including water or steam distillation, solvent extraction, expression under pressure, supercritical fluid and subcritical water extractions (EDRIS, 2007). Many of the volatile substances have a wide range of biological activity such as

\footnotetext{
${ }^{1}$ Faculty of Natural Sciences and Mathematics, University of Sarajevo
} 
physiological function of plant growth, development, interaction with the environment, response to pathogen attack and stress (WINK, 2003). They also posses antimicrobial, antiviral, antimycotic, antioxigenic, antiparasitic and insecticidal properties (LAMIRI ET AL., 2001; JUGLAL ET AL., 2002; MOON ET AL., 2006; MICHAELAKIS ET AL., 2007). Despite numerous studies about antimicrobial potential of essential oils (Deans ANd Ritchie, 1987; KNobloch et Al., 1989; NyChas, 1995, De Silva, 1996, Wang et AL., 1998; Hammer et AL., 1999; Dorman and Deans, 2000; DeriU et AL., 2007; CeliKel and KAVAS, 2008; ĆAVAR ET AL., 2008), the mechanisms of these activities are not yet fully understood. Many studies have demonstrated the antimicrobial activity of different essential oils in vitro, but there is very little information on this topic in in vivo treatments (BASER AND BUCH BAUER,2010).

Concerning the phytopathogenic viruses, various substances of natural and synthetic origin have been used for control of virus infection, but only a few studies have revealed the antiphytoviral activity of pure essential oils (BISHOP, 1995; OTHMAN AND SHoman, 2004; DunKIĆ ET AL., 2010, 2011; BeZIĆ ET AL., 2011). This study investigatest he effects of cajuput, common myrtus and winter savory essential oils on Tobacco mosaic virus replication in different plant hosts.

\section{MATERIAL AND METHODS - Materijal i metode}

\section{Essential Oils - Eterična ulja}

Table 1. Essential oils tested for antiphytoviral activity

Tabela 1. Eterična ulja testirana na antifitoviralnu aktivnost

\begin{tabular}{|c|c|c|c|}
\hline Essential oil & Plant organ & Country of origin & Major chemical costituents \\
\hline Cajuput & Leaf & Indonesia & $\begin{array}{l}58 \% 1,8 \text {-cineole } \\
8 \% \alpha \text {-terpineol }+ \text { terpenyl- } \\
\text { acetate } 5 \% \text { limonene } \\
3.9 \% \alpha \text {-pinene } \\
2.1 \% \beta \text {-pinene }\end{array}$ \\
\hline Common myrtle & Leaf & Germany & $\begin{array}{ll}25 \% & \alpha \text {-pinene } \\
25 \% & 1,8 \text { cineole } \\
20 \% & \text { limonene } \\
10 \% & \gamma \text {-terpinene } \\
10 \% & \text { tannin } \\
3 \% & \text { linalool }\end{array}$ \\
\hline Winter savory & Flower & Hungary & $\begin{array}{ll}55 \% & \text { carvacrol } \\
17 \% & \text { paracymene } \\
5.8 \% & \text { thymol } \\
3.3 \% & \gamma \text {-terpinene } \\
2.5 \% & \alpha \text {-pinene }+\alpha \text {-thujene } \\
2.4 \% & \text { myrcene }\end{array}$ \\
\hline
\end{tabular}


Essential oils of cajuput (Melaleuca leucadendron (L.) L.), common myrtle (Myrtuscommunis L.) and winter savory (Satureja montana L.) were screened for antiphytoviral activity (Table 1.). Cajuput and winter savory oils were produced by Oshadhi (Germany), while common myrtle oil was produced by Caelo (Germany).

\section{Virus strain - Virusni soj}

Tobacco mosaic virus vulgare strain (PV-0107) was purchased from DSMZ, Germany. Virus was maintained and propagated in tobacco (Nicotiana tabacum L. 'White Barley') plants.

\section{Test plants - Pokusne biljke}

Test plants used in this study were: Chenopodium quinoa Willd., Cucumis sativus L. 'Cornishon' and Phaseolus vulgaris L. 'Top Crop'. Plants were grown in a greenhouse under constant temperature $\left(23{ }^{\circ} \mathrm{C}\right)$ and the artificial light $(18 \mathrm{~h}$ photo period) with watering as required. Experimental plants $C h$. quinoa were mechanically inoculated at the four-leaf stage, while $C$. sativus and $P$. vulgaris were inoculated at the two-leaf stage. Plants selected for study were uniform in size as much as possible.

\section{Preparation of inoculum - Priprema inokuluma}

Viral inoculum was prepared from TMV infected tobacco 'White Barley' leaves ground with previously cooled inoculation buffer $(0.06 \mathrm{M}$ phosphate buffer, $\mathrm{pH}$ 7.0) in a porculan mortar. Leaf extract was diluted with the same inoculation buffer to give a suitable number of discrete local lesions on test plants. Viral inoculum prepared in this way was used to inoculate test plants. Essential oils were mixed with Tween 80 and added directly to viral inoculum to get the final concentrations of 1,2 and $3 \mu 1 / \mathrm{ml}$.

\section{Infectivity bioassays - Biološka testiranja}

Antiphytoviral activity of the essential oils against TMV was determined by the half-leaf method. Left half of the leaf was inoculated with the virus inoculum and the right half of the same leaf was inoculated with the virus inoculum containing essential oil. Leaves were rinsed with tap water immediately after inoculation. All treatments were repeated three times and inoculated plants were grown in a greenhouse. Local lesions were counted 7 days after inoculation on $C$. quinoa and $C$. sativus leaves and 14 days after inoculation on $P$. vulgaris leaves. 


\section{Determination of virus inhibition percentage - Odredivanje procenta inhibicije virusa}

Percentage of virus inhibition was calculated by comparing the number of viral lesions on the two leaf halves according to the formula (DUNKIĆ et al. 2010):

where by:

$$
I P=\frac{C K-A}{C K} \times 100
$$

IP = viral inhibition in \%,

$\mathrm{CK}=$ average number of viral lesions on the control group,

$\mathrm{A}=$ average number of viral lesions on the essential oil treated group.

\section{Statistical analysis - Statističke analize}

The significance of difference between mean values of local lesions number for oil-treated and untreated halves of leaves was estimated statistically using one tailed Student t-test (GraphPad InStat software).

\section{RESULTS - Rezultati}

Three essential oils were screened for in vivo antiphytoviral activity using the half-leaf method. The more powerfull the antiviral effect of the essential oil is, the larger reduction of viral lesions number is recorded. All tested essential oils exhibited high levels of inhibitory effects against TMV in the experimental plants.

The percentage of virus inhibition caused by cajuput essential oil in concentrations of 1,2 and $3 \mu \mathrm{l} / \mathrm{ml}$ ranged from 37.28 to $100 \%$. (Graph 1.) The best effects cajuput oil showed in experimentally infected Ch. quinoa plants, which caused $100 \%$ inhibition of TMV replication in all tested concentrations.

When it comes to common myrtus oil, it is proved to be the most effective against TMV in inoculated Ch. quinoa hosts at $3 \mu \mathrm{l} / \mathrm{ml}$ concentration (Graph 2.) However, lower concentrations of this oil demonstrated the strongest virus inhibition in local lesion host $C$. sativus.

Among tested essential oils, winter savory essential oil showed the best antyphytoviral effects. This essential oil caused reduction in lesions number in the plant hosts with reductions estimated to be from 46.34 to $100 \%$ (Graph 3.). The $100 \%$ virus inhibition was recorded in all applied concentrations of winter savory oil in plant host Ch. quinoa. 


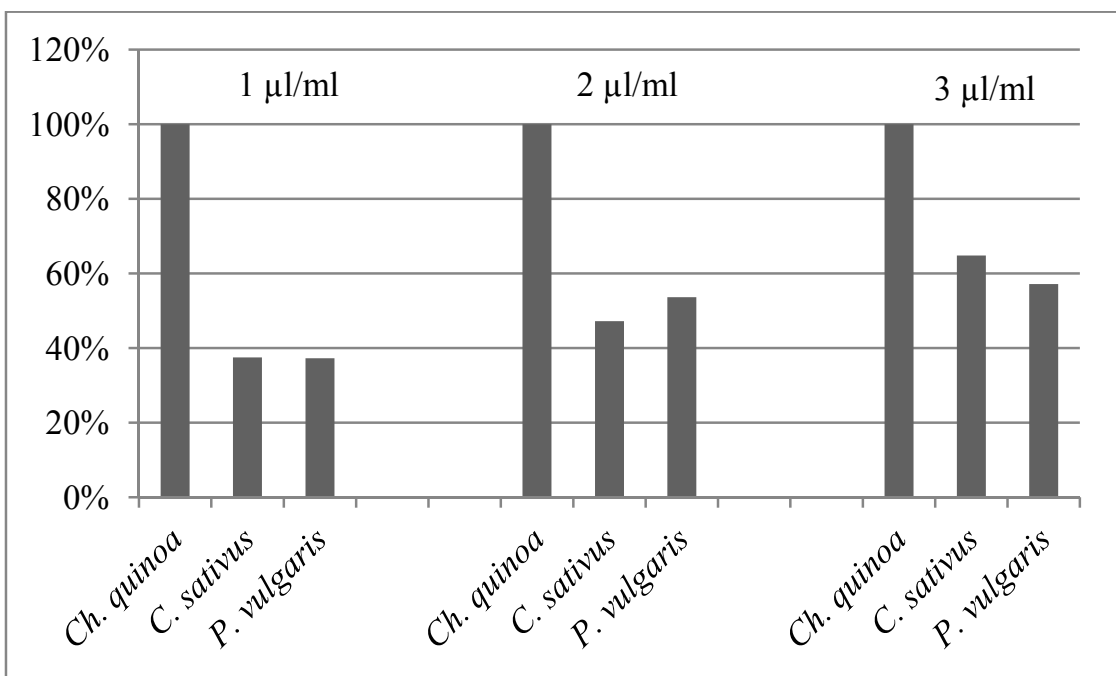

Graph 1. Effect of cajuput (Melaleuca leucadendron) essential oil on TMV infectivity Grafik 1. Učinak eteričnog ulja kajeputa (Melaleuca leucadendron) na infektivnost TMV-a

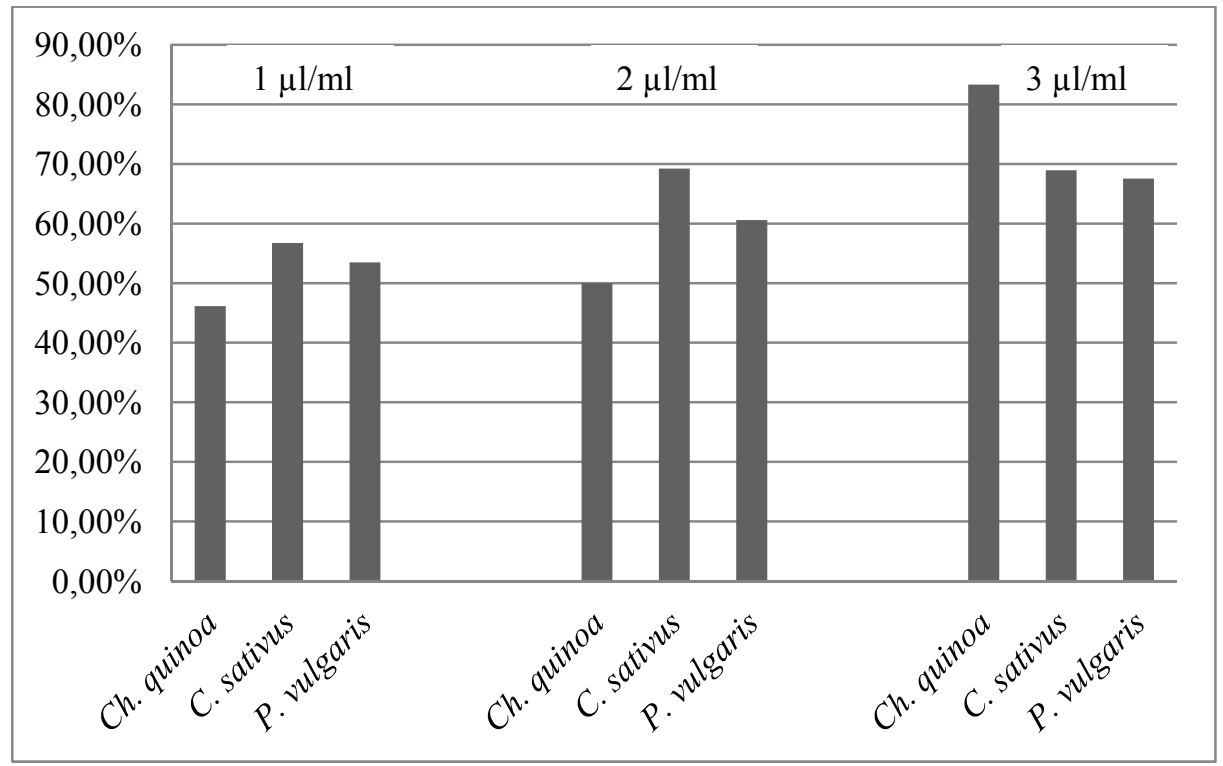

Graph 2.Antiviral action of common myrtle (Myrtus communis) essential oil on TMV Grafik 2. Antiviralno djelovanje eteričnog ulja mirte (Myrtus communis) na TMV 


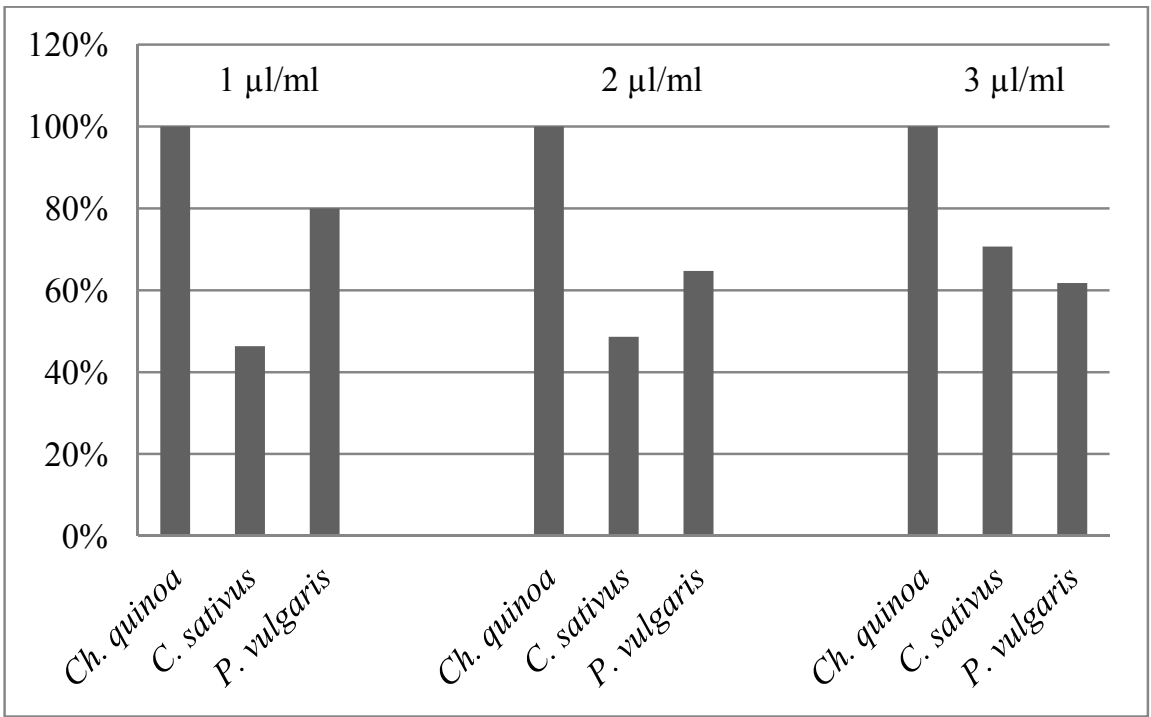

Graph3. Antiphytoviral properties of winter savory (Satureja montana) essential oil on TMV Grafik 3. Antifitoviralna svojstva eteričnog ulja primorskog vriska (Satureja montana) na TMV

Results of statistical analysis showed that tested essential oils significantly inhibited TMV infections in all applied concentrations (Table 2.).

Table 2. Results of Student t-test

Tabela 2. Rezultati Studentovog t-testa

\begin{tabular}{|l|c|c|c|}
\hline \multirow{2}{*}{\multicolumn{1}{|c|}{ Essential oil }} & \multicolumn{3}{|c|}{ Calculated p-value } \\
\cline { 2 - 4 } & $1 \mu \mathrm{l} / \mathrm{ml}$ & $2 \mu \mathrm{l} / \mathrm{ml}$ & $3 \mu \mathrm{l} / \mathrm{ml}$ \\
\hline Cajuput & $0.037532^{\mathrm{a}}$ & $0.011304^{\mathrm{b}}$ & $0.007214^{\mathrm{c}}$ \\
\hline Common myrtle & $0.010978^{\mathrm{a}}$ & $0.009573^{\mathrm{b}}$ & $0.000212^{\mathrm{c}}$ \\
\hline Winter savory & $0.022294^{\mathrm{a}}$ & $0.018399^{\mathrm{b}}$ & $0.004137^{\mathrm{c}}$ \\
\hline
\end{tabular}

All values arepresentedas the mean value \pm standard deviation measurements. Supercript letters $(\mathrm{a}, \mathrm{b}$ and $\mathrm{c})$ indicate significant differences $(\mathrm{p}<0.05)$.

\section{DISCUSSION - Diskusija}

Today, thanks to antibiotics, the most bacterial infections are mainly under control. However, this is not the case with viral infections. Many of the more than 700 known plant viruses cause devastating diseases and often have wide host ranges (STRANGE AND SCOTT, 2005). Because of the serious losses they cause to forestry, agriculture and horticulture, virus diseases have acquired great importance in the 
realm of plant pathology and call for effective management measures against them. Unlike fungicides and bactericides, no commercial viricides have yet been developed (SASTRY AND ZITTER, 2014). Virus is an unique pathogen which utilizes the host cell environment and cellular factors for its propagation. This unique feature of viruses makes it difficult to design a treatment to attack the virus or its replication directly without any adverse effects on the infected cells (KITAZATO ET AL., 2007). Many viruses cause epidemics and pandemics, which are very difficult or impossible to control by chemical application. One of the most promissing approaches to treat viral infections is use of plants and their products. Plants have an almost limitless ability to synthesize aromatic substances, most of which are phenols or their oxygen-substituted derivatives (COWAN, 1999). Regarding phytopathogenic viruses, various substances of natural and synthetic origin have been assessed for their antiphytoviral activity (OTHMAN AND SHOMAN, 2004). Several compounds have been identified that inhibit the replication of TMV like bitriazolyl compounds, tylophorine B (XIA ET AL., 2006), phanantherene-based tylophorine derivatives (WANG ET AL., 2010a), derivatives of thiadiazole acetamide (ZHAO ET AL., 2006), cyanoaweylate derivates (CHEN et al. 2008) and racemic phenanthroindolizidine alkaloids or pure alkaloids (WANGet al. 2010b).

To our knowledge, only a few studies have revealed the antiphytoviral activity of pure essential oils (BISHOP, 1995; DUNKIĆ ET AL., 2010, 2011; BEZIĆ ET AL., 2011). In our experiment, antiviral efficacy of essential oils from cajuput, common myrtle and winter savory were tested in vivo against Tobacco mosaic virus.

The results showed that all of the oils used for screening were effective in reducing the number of local lesions formed by the inoculation of TMV. It was previously reported that essential oils of cajuput and winter savory possess an inhibitory activities against this virus (BISHOP, 1995; BEZIĆ ET AL., 2011), but antiphytoviral activity of the common myrtus oil has not been tested so far. Our research confirmed that common myrtle oil also exhibited antiviral effects against TMV.

\section{CONCLUSIONS - Zaključci}

Tested essential oils of cajuput, common myrtle and winter savory demonstrated significant level of effectiveness against Tobacco mosaic virus. Our results demonstrated that winter savory essential oil showed the highest and broadest inhibition of TMV. The percentage of virus inhibition with the value of $100 \%$ was recorded in all tested concentrations of cajuput essential oil in Chaenopodium quinoa experimental plants. According to the available literature data, this is the first study of myrtle essential oil as antiphytoviral agent. All experiments have been performed in vivo, which is rare in the investigation of antiviral effects of plant substances. These results suggest that investigated essential oils might be useful in the control of plant virus diseases. 
In the future, it is necessary to identify the farmacodynamic characteristics and precise mechanisms of essential oils activity against viruses, which would lead to broader use of these plant secondary metabolites as alternative and environmentally friendly antiviral substances.

\section{REFERENCES - Literatura}

BAser, K.H.C., Buchbauer, G. (2010): Handbook of essential oils. Science, Technology and Applications. Boca Raton: CRC Press, Taylor \& Francis Group.

BASSOLE, I.H.N., JULIANI, R. (2012): Essential Oils in Combination and Their Antimicrobial Properties. Molecules, 17: 3989-4006.

Bezić, N., Vuko, E., Dunkić, V., Ruščı́́, M., BLAŽEvić, I, BuRčul, F. (2011): Antiphytoviral activity of sesquiterpene-rich essential oils from four Croatian Teucrium species. Molecules, 16: 8119-8129.

BISHOP, C.D. (1995): Antiviral activity of the essential oil of Melaleuca alternifolia (Maiden \& Betche) Cheel (tea tree) against tobacco mosaic virus. Journal of Essential Oil Research, 7:641-644.

Celikel, N., Kavas, G. (2008): Antimicrobial properties of some essential oils against some pathogenic microorganisms. Czech Journal of Food Sciences, 26(3): 174181.

Chen, Z., WANG, X., Song, B., Wang, H., BhaduRY, P.S., YAN, K., Zhang, H., Yang, S., JiN, L., Hu, D., XUe, W., Zeng, S., Wang, J. (2008): Synthesis and antiviral activities of novel chiral cyanoacrylate derivatives with (E) configuration. Bioorganic and Medicinal Chemistry Letteers, 16(6): 3076-3083.

CoWAN, M M. (1999): Plant products as antimicrobial agents. Clinical Microbiology Review, 12(4): 564-582.

Ćavar, S., Maksimović, M, Šolić, M.E., Jerković-Mujkić, A., BeštA, R. (2008): Chemical composition and antioxidant and antimicrobial activity of two Satureja essential oils. Food Chemistry, 111: 648-653.

DeSILVA, T.K. (1996): A manual on the essential oil industry. United Nations Industrial Development Organization,Vienna, Austria.

Deans, S.G., Ritchie, G. (1987): Antibacterial properties of plant essential oils. International Journal of Food Microbiology,5: 165-180.

Deriu, A., Branca, G., Molicotti, P. (2007): In vitro activity of essential oil of Myrtus communis L. against Helicobacter pylori. International Journal of Antimicrobial Agents, 30(6): 562-563.

Dorman, H., DEANS, S. (2000): Antimicrobial agents from plants: antibacterial activity of plant volatile oils. Journal of Applied Microbiology,88: 308-316. 
Dunkić, V., BezIć, N., VuKo, E., CuKRoV, D. (2010): Antiphytoviral Activity of Satureja montana L. ssp. variegata (Host) P. W. Ball Essential Oil and Phenol Compounds on CMV and TMV. Molecules, 15, 6713-6721.

DUNKIĆ, V., BEZIĆ, N., VUKO, E. (2011): Antiphytoviral activity of essential oil from endemic species Teucrium arduini L. NaturalProducts Communication,6: 13851388.

EDRIS, A. (2007): Pharmaceutical and therapeutic potentials of essential oils and their individual volatile constituents: A review. Phytotherapy Research, 21: 308-323.

Hammer, K., CARSON, C., RILey, T. (1999): Antimicrobial activity of essential oils and other plant extracts. Journal of Applied Microbiology,86: 985-990.

Juglal, S., Govinden, R., OdhaV, B. (2002): Spice oils for the control of co-occurring mycotoxin-producing fungi. Journal of Food Protection, 65: 683-687.

KitazAto, K., Wang Y., Kobayashi, N. (2007): Viral infectious disease and natural products with antiviral activity. Drug Discovery and Therapeutics, 1(1):14-22.

KNobloch, K., Pauli, A., IBerl, B.,Weigand, H., Weis, N. (1989): Antibacterial and antifungal properties of essential oil components.Journal of Essential Oils Research, 1: 119-128.

LAmiRI, A., Lhaloul, S., BenJILALI, B., BeRRAdA, M. (2001): Insecticidal effects of essential oils against Hessian fly, Mayetiola destructor (Say). Field Crops Research, 71: 9-15.

Michaelakis, A., Theotokatos, S.A., Koliopoulos, G., Chorianopoulos, N.G. (2007): Essential oils of Satureja species: insecticidal effects on Culex pipens larvae (Diptera: Culicidae). Molecules, 12: 2567-2578.

Moon, T., Wilkinson, J.M., Cavanagh, H.M.A. (2006): Antiparasitic activity of two Lavandula essential oils against Giardia duodenalis, Trichomonas vaginalis and Hexamita inflata. Parasitology Research, 99: 722-728.

NYCHAS, G.J.E. (1995). Natural antimicrobials from plants. In: Gould G.W. (ed.) New methods of food preservation (1st ed.), pp. 58-89, Blackie Academic \& Professional, London.

Othman, B.A., Shoman, S.A. (2004): Antiphytoviral activity of the Plectranthus tenuiflorus on some important viruses. International Journal of Agriculture and Biology, 6: 844-849.

Pichersky, E., Noel, J.P., Dudareva, N. (2006): Biosynthesis of plant volatiles: Nature's diversity and ingenuity. Science, 311: 808-811.

RedžIĆ, S., TUKA, M., PAJEVIĆ, A. (2006): Research into microscopic structure and essential oils of endemic medicinal plant species Satureja subspicata Bartl. ex Vis. (Lamiaceae). Bosnian Journal of Basic Medical Sciences, 6(2): 25-31.

SASTRY, K.S., ZITTER, A. (2014): Plant virus and viroid diseases in the tropics. Volume 2: Epidemiology and Management. Springer, New York. 
Strange, R.N., Scott, P.R. (2005): Plant disease: A Threat to Global Food Security. Annual Review of Phytopathology, 43: 83-116.

Wang, M., Li, J., Rangarajan, M., ShaO, Y., Lavole, E.J., Huang, T.C., Ho, C.T. (1998): Antioxidantive phenolic compounds from sage (Salvia officinalis). Journal of Agricultural and Food Chemistry, 46: 4869-4873.

WANG, K., HU, Y., LIU, Y., MI, N., FAN, Z., LIU, Y., WANG, Q. (2010a): Design, synthesis, and antiviral evaluation of Phenanthrene-based tylophorine derivatives as potential antiviral agents. Journal of Agriculture and Food Chemistry, 58(23): 12337-12342.

Wang, K., Su, B., Wang, Z., Wu, M., LI, Z., Hu, Y., Fan, Z., Mı, N., WANG, Q. (2010b): Synthesis and antiviral activities of Phenanthroindolizidine alkaloids and their derivatives. Journal of Agriculture and Food Chemistry 58(5): 2703-2709.

WALLACE, R.J. (2004): Antimicrobial properties of plant secondary metabolites. Proceedings of the Nutrition Society, 63: 621-629.

WINK, M.(2003). Evolution of secondary metabolites from an ecological and molecular phylogenetic perspective. Phytochemistry, 64: 3-19.

XIA, Y., Fan, Z., YAO, J., LIAO, Q., LI, W., QUa, F., Peng, L. (2006): Discovery of bitriazolyl compounds as novel antiviral candidates for combating the Tobacco mosaic virus. Bioorganic and Medicinal Chemistry Letteers, 16: 2693-2698.

ZHAO, W.G., WANG, J.G., LI, Z.M., YANG, Z. (2006): Synthesis and antiviral activity against Tobacco mosaic virus and 3D-QSAR of alpha-substituted-1,2,3thiadiazoleacetamides. Bioorganic and Medicinal Chemistry Letteers 16(23): 6107-6111.

\section{SAŽETAK}

Mnogo godina se antiviralno djelovanje eteričnih ulja manje istraživalo u odnosu na njihov negativan učinak na druge mikrobe. U novije vrijeme, in vitro je dokazana antiviralna aktivnost mnogih eteričnih ulja, a u najvećem broju istraživanja korišteni su animalni i humani virusi sa ovojnicom. Antifitoviralno djelovanje eteričnih ulja nije sistemski istraživano na području naše zemlje, ali ni regije, pa trenutno postoji nedovoljno informacija o efektima eteričnih ulja na viruse i viralne infekcije u biljnim domaćinima. Budući da dosadašnji tretmani suzbijanja virusa hemijskim supstancama nisu dali dobre rezultate, a antifitoviralno djelovanje eteričnih ulja je relativno slabo istraženo, glavni cilj ovog istraživanja bio je izvršiti in vivo ispitivanje antifitoviralnog djelovanja eteričnih ulja kajeputa (Melaleuca leucadendron (L.) L.), mirte (Myrtus communis L.) i primorskog vriska (Satureja montana L.) na virus mozaika duhana, koji inficira preko 200 vrsta biljaka iz oko 30 porodica. Virus mozaika duhana, soj vulgare (TMV PV-0107) je propagiran u dijagnostičkim biljkama duhana (Nicotiana tabacum L. 'White Barley'), nakon čega je izvršena 
mehanička inokulacija diferencijalnih biljnih domaćina virusa: kvinoje (Chenopodium quinoa Willd.), krastavca (Cucumis sativus L.) i graha (Phaseolus vulgaris L.).

Virusni inokulum je pripremljen od listova N. tabacum L. 'White Barley' inficiranih TMV-om. Sistemično inficirani lisni materijal je odrezan sterilnim žiletom i homogeniziran u tarioniku pomoću prethodno ohlađenog $0.06 \mathrm{M}$ fosfatnog pufera, $\mathrm{pH}$ 7.0. Za inokulaciju pokusnih biljaka je korištena tzv. metoda pola lista. Na lijevu (kontrolnu) polovinu lista nanesen je čisti viralni inokulum, a na desnu (eksperimentalnu) polovinu lista inokulum koji je sadržavao eterično ulje. U ispitivanju antifitoviralnog djelovanja odabranih eteričnih ulja, korištene su koncentracije od 1,2 i $3 \mu \mathrm{l}$ eteričnog ulja/ml infektivnog soka. Postotak inhibicije virusa je izračunat na osnovu utvrđenog broja viralnih lezija na eksperimentalnoj i kontrolnoj polovini lisne lamine, a statistička signifikantnost razlike između prosječnog broja lezija na kontrolnoj i eksperimentalnoj polovini lista je procijenjena korištenjem Studentovog t-testa, na nivou značajnosti od 5\%.

Sva testirana eterična ulja su pokazala visok nivo učinkovitosti protiv TMV-a. Postotak virusne inhibicije eteričnim uljem kajeputa bio je najveći u eksperimentalnim biljkama Ch. quinoa, a iznosio je $100 \%$ u svim testiranim koncentracijama, dok je eterično ulje primorskog vriska uzrokovalo najvišu i najširu inhibitornu aktivnost na virus mozaika duhana, respektirajući različite koncentracije i diferencijalne biljne domaćine.

Eterično ulje mirte je ovim istraživanjem prvi put testirano kao antifitoviralni agens, a visok nivo virusne inhibicije koju uzrokuje sugerira njegovu potencijalnu upotrebu u kontroli viroza. Svi eksperimenti su izvedeni in vivo, što je rijetkost u istraživanju antiviralnog djelovanja biljnih supstanci. U narednom periodu potrebno je izvršiti identifikaciju farmakodinamičkih karakteristika i istražiti precizne mehanizme djelovanja eteričnih ulja na viruse, čime bi se proširio spektar upotrebe ovih biljnih sekundarnih metabolita kao alternativnih antimikrobnih supstanci. 